\title{
ANALISA BENTUK FURNITUR SEBAGAI MEDIA DUDUK PADA AREA FOODTRUCK
}

\author{
Desy Dwi Putri', Rangga Firmansyah ${ }^{2}$ \\ Fakultas Industri Kreatif, Universitas Telkom \\ 1Desi2putri@gmail.com, ${ }^{2}$ Rangga.Firmansyah@gmail.com
}

\begin{abstract}
Abstrak : pada dasarnya pengaplikasian Foodtruck pada masyarakat modern dikelompokkan sebagai media penjualan yang dituntut untuk bergerak bebas dengan pertimbangan lokasi yang dapat berubah-ubah, pada aplikasi desain foodtruck harus mencangkup efisiensi dalam mobilisasi dan interior yang sesuai dengan karakter foodtruck, yaitu pemanfaatan elemen interior sebagai opsional paking yang harus dipertimbangkan dalam metode desain foodtruck, termasuk diantaranya furniture yang mendominasi tata letak ruangan. Perancangan Furniture pada area foodtruck menjadi landasan dalam permainan bentuk yang menjawab permasalahan sebuah aktivitas.Proses untuk menghasilkan sebuah objek yang memiliki nilai yang tinggi dari ekonomi, estetika dan fungsional. Dalam metode pengaplikasian geometri terhadap sebuah stool dapat dijadikan acuan dalam konstruksi, penunjang aktivitas, kapasitas dan integritas dari hasil sebuah proses perancangan, pada stool terdapat beberapa identifikasi masalah yang mendasar dan memiliki keterkaitan terhadap prosestransformasi geometri yang seharusnya dan mengkaji kesalahan apa saja yang harus dihindari dalam sebuah perancangan stool dengan tujuan memenuhi standar, untuk meminimalisir kesalahan dalam sebuah konsep perancangan stool yang bermain dalam ruang lingkup geometri dan transformasi bentuk.
\end{abstract}

Kata Kunci : Bentuk Geometri, Foodtruck, Stool

\begin{abstract}
Basically the application of Foodtruck in modern society is classified as a sales medium that is required to move freely with consideration of location that can change, in the application of foodtruck design must include efficiency in mobilization and interior that is in accordance with the character of foodtruck, namely the use of interior elements as optional gasket that must be considered in the foodtruck design method, including furniture that dominates the layout of the room. Furniture design in the foodtruck area becomes the foundation in the form of rules that answer the problem of an activity. The process to produce an object that has a high value of economic, aesthetic and functional. In the method of applying geometry to a stool can be used as a reference in construction, supporting activities, capacity and integrity of the results of a design process, in the stool there are some basic problem identification and relevance to the geometry transformation process and examine any errors that must be avoided in a stool design with the aim of meeting standards, to minimize errors in a design concept stool that plays in the scope of geometry and shape transformation.
\end{abstract}

Keywords: Geometry Form, Foodtruck, Stool

\section{PENDAhuluan}

Pada pengembangan produk, sebuah objek harus memiliki nilai untuk ketercapaian peranan yang dihasilkan dengan metode desain. Foodtruck adalah objek desain yang menjadi area penting dalam peran penataan furniture terhadap aktifitas ruang berdasarkan fungsi, ukuran dan sifat aksebilitas dalam penerapan desain sebagai pelengkap foodtruck.

Proses untuk menghasilkan sebuah objek yang memiliki nilai yang tinggi dari ekonomi, estetika dan fungsional. Elemen yang sangat berpengaruh terhadap aktifitas pengguna ruang adalah furniture sebagai ikon utama pengisi ruang dalam aktifitasnya. Mebel atau furniture yang memiliki ketercapaian fungsional, estetika dan nilai ekonomisnya mampu dicapai oleh pengguna menjadi salah satu yang berpengaruh dari proses ketercapaian desain, akan tetapi dari hasil perancangan 
furniture yang beragam timbul masalah dalam aktifitas pengguna ruang, berbagai faktor yang identik dengan pola perancangan maupun kesesuaian fungsional terhadap pemakaian.

Objek yang menjadi sasaran pencapaian adalah stool, jenis mebel ini adalah salah satu objek yang simple dan sering digunakana dalam aktifitas sehari-hari, namun dengan desain yang sederhana masih memiliki aturan yang tidak seharusnya digunakan sehingga menimbulkan permasalahanpermasalahan yang berulang pada setiap perancangan. Pada proses penelitian, ketercapaian objek dalam pengaruh ketidaksesuaian desain dan hal-hal yang harus diperhatikan mengacu pada proses perancangan stool, penggunaan transformasi yang tidak sesuai dengan struktur duduk manusia hingga ketercapaian posisi duduk yang nyaman dan sesuai dengan pengguna.

Pada beberapa kasus kerusakan struktur tubuh disebabkan oleh ketidaksesuain posisi dalam ruang gerak interior dan pembebanan terhadap aspek pergerakan manusia terhadap objek, pada stool terdapat beberapa identifikasi masalah yang mendasar dan memiliki keterkaitan terhadap proses penelitian

- Ukuran yang tidak sesuai dengan bentuk dan struktur tubuh pengguna, ada yang terlalu tinggi dan terlalu rendah untuk standar sebuah media duduk.

- Standar yang berlaku lebih mengacu pada standar barat, tidak memiliki standar khusus pengguna dengan proporsi ukuran tubuh orang Indonesia.

- Bentuk transformasi yang ekstreme sehingga kenyamanan dalam posisi dudukan tidak maksimal.

- Geometri dasar yang tidak sesuai dengan proses awal perancangan atau ketidak tercapainya sebuah proses desain sehigga hasil desain bermasalah terhadap pengguna.

- Struktur maupun kontruksi yang tidak sesuai dengan arah ikatan antar material.

- Jenis material yang dipilih terhadap penggunaan objek dalam keseharian.

- Jenis finishing yang tidak sesuai dalam penggunaanya.

- Ketidaktercapaian standarisasi dalam sebuah tujuan perancangan.

- Transformasi dasar yang tidak sesuai dengan objek awal transformasi sehingga dari fungsi estetika tidak memiliki ketercapaian bentuk.

- Transformasi bentuk yang menjiplak tanpa adanya proses desain yang inivatif dan tetap membawa hasil dari transformasi objek terhadap sebuah bentuk.

Tujuan menjadi salah satu acuan yang digunakan oleh desainer untuk mendesain stool yang memenuhi standar, dan meminimalisir kesalahan dalam sebuah konsep perancangan stool yang bermain dalam ruang lingkup geometri dan transformasi bentuk. Manfaatnya adalah sebagai terobosan dalam bidang pendidikan dan bermanfat bagi masyarakat, baik dari perancangaan stool maupun pengguna stool.

Furniture berasal dari bahasa Perancis fourniture, dari fournir atau 'to furnish' yang berarti pelengkap ruangan atau bangunan. Menurut Concise Oxford Dictionary, mebel diartikan sebagai:

- the movable articles that are used to make a room or building suitable for living or working in, such as table, chairs, or desk

- the small accessories or fitting that are required for a particular task or function 
Berdasarkan pengertian furniture menurut bahasa dan artian secara umum, maka furniture dapat berarti sebagai bagian dari ruang gerak interior, dimana yang beperan penting dalam suatu efektifitas ruang gerak manusia dalam kebutuhan ruang dan pendukung aktifitasnya. Aktifitas pada area foodtruck juga membutuhkan peran furniture sebagai pelengkap dalam ruang gerak dalam batasan pengguna jasa maupun pemberi jasa.

Menurut Horatio Greenough dalam (Sutrisno, 1984) terdapat hubungan erat antara bentuk, fungsi, dan alam. Ia memperkenalkan form follow function (bentuk mengikuti fungsi) dengan dua prinsip utama: bentuk akan berubah jika fungsi berubah dan fungsi baru tidak mungkin diikuti bentuk lama. Sehingga dalam aplikasi penelitian ini membahas bentuk yang mengikuti fungsi digunakan untuk standar foodtruck, bentuk yang mendukung system stacking atau holding untuk mempermudah aksebilitas dalam aktifitas foodtruck.

Prinsip-prinsip umum desain kursi menurut Pheasant (1987): Ukuran dan bentuk dasar dari beberapa kursi harus ditentukan dengan pertimbangan-pertimbangan ukuran Antropometri.

- Tinggi kursi harus tidak terlalu tinggi dari popliteal pemakai;

- Kedalaman kursi (dari depan sampai sandaran) harus tidak terlalu besar dari jarak pantat-popliteal dari pemakai yang pendek;

- Lebar tempat duduk di antara sandaran tangan harus memberikan kelonggaran untuk pemakai yang lebar ( 95 percentil) lebar pinggul;

- Tanpa sandaran tangan lebar tempat duduk dapat sedikit lebih kecil daripada lebar pinggul;

- Sandaran punggung harus didesain untuk menyangga berat tubuh para pemakai;

- Sudut sandaran punggung harus ditentukan sesuai dengan fungsi tempat duduk. Sudutnya $100^{\circ}-110^{\circ}$ dari horisontal untuk kursi kerja dan $110^{\circ}-120^{\circ}$ untuk kursi istirahat;

- Permukaan / bagian atas kursi harus datar.

Menurut Sutrisno (1984) Stool merupakan sebuah fasilitas duduk yang secara visual tidak memiliki sandaran punggung dan sandaran tangan. Berdasarkan sejarah perkembangan mebel, stool sudah hadir dari jaman/ abad klasik dan pertengahan. Pada umumnya, kehadiran stool pada jaman ini adalah sebagai simbol kebanggaan/ gengsi. Fungsi dari stool adalah sama dengan fasilitas duduk (kursi) pada umumnya, yaitu untuk memfasilitasi aktifitas manusia untuk menopang bagian tubuhnya dalam bekerja ataupun beristirahat. Tetapi beberapa elemen kursi tidak dimiliki oleh stool, seperti sandaran punggung dan sandaran tangan. Oleh karena itu kenyamanan yang baik pada bagian dudukan diperlukan. Karena pada bagian tersebut kenyamanan standar tubuh manusia ditompang.

Jenis dudukan : stool (kursi tanpa senderan)dengan komponen konstruksi detail yang bisa digunakan untuk aplikasi desain adalah sebagai berikut : 


\section{Bibir miring}

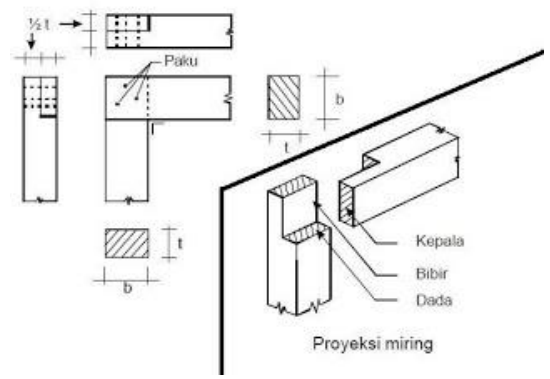

Bibir lurus

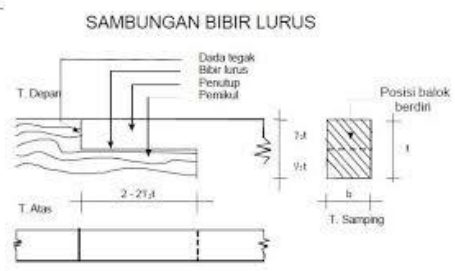

\section{Lidah alur}

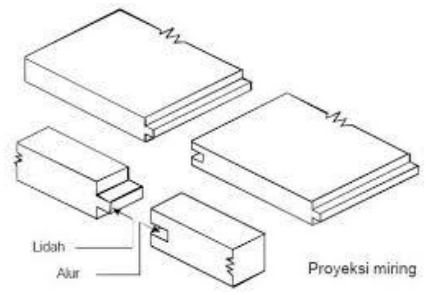

\section{Proyeksi miring}

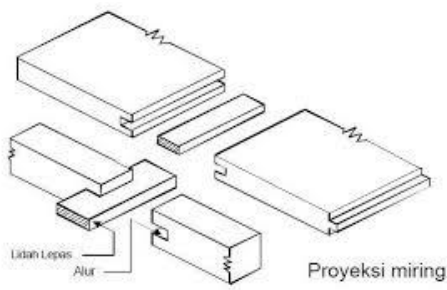

Schei bibir miring berkait

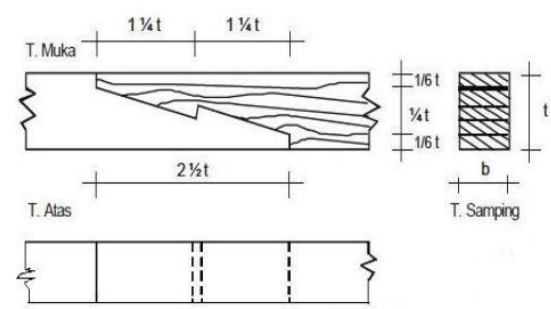

bersusun dengan gigi

SAMBUNGAN BERSUSUN DFNGAN GIGI

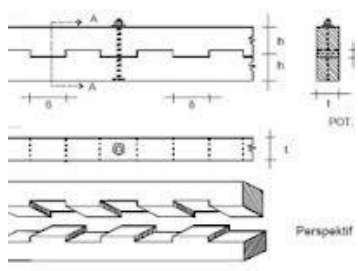

lidah lepas alur

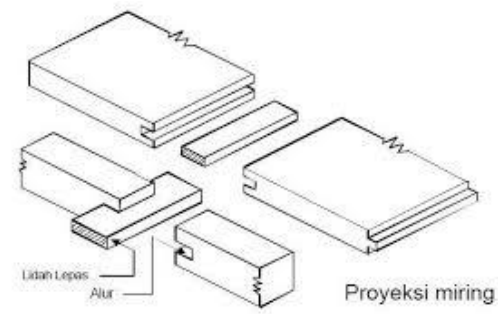

pengunci bawah

SAMBUNGAN DENGAN PENGUNCI DI BAWAH
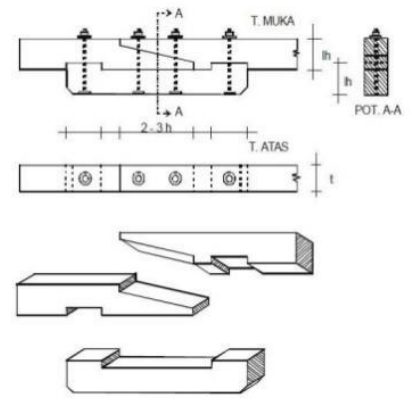

takikan lurus tangkap 
SAMBUNGAN BERSUSUN DENGAN SCHEI

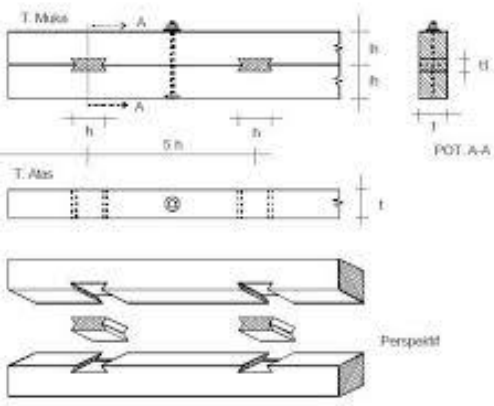

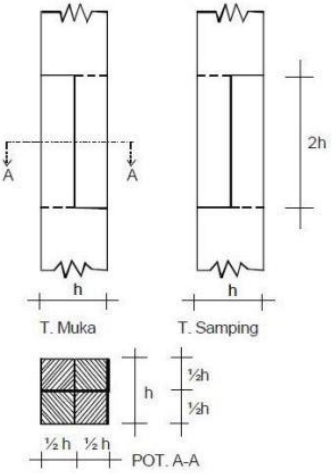

Gambar 1. jenis-jenis joint (Sumber:Tikno,I 2008)

Standar ergonomi pada dudukan tanpa sandaran adalah sma dengan dudukan lainnya, dengan referensi dari standar barat, penggunaan ukuran disesuaikan dengan buku human dimension dan sumber dari Vitruvius seperti yang disebutkan pada gambar dibawah ini:
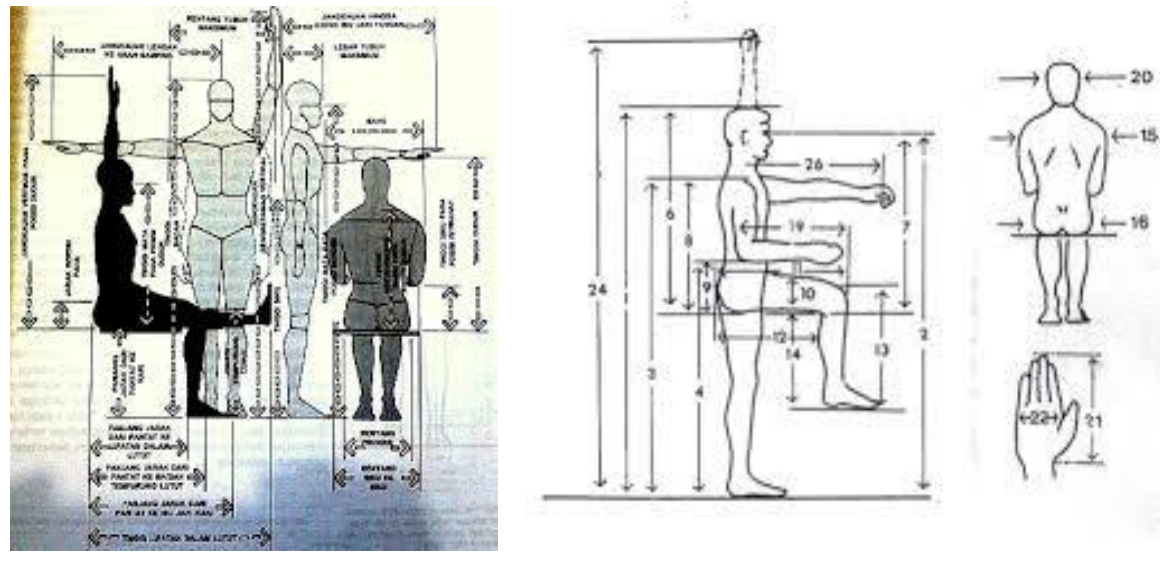

Gambar 2. Proporsi Tubuh Manusia. (Sumber: Panero,2003)

Ukuran proporsional posisi duduk manusia

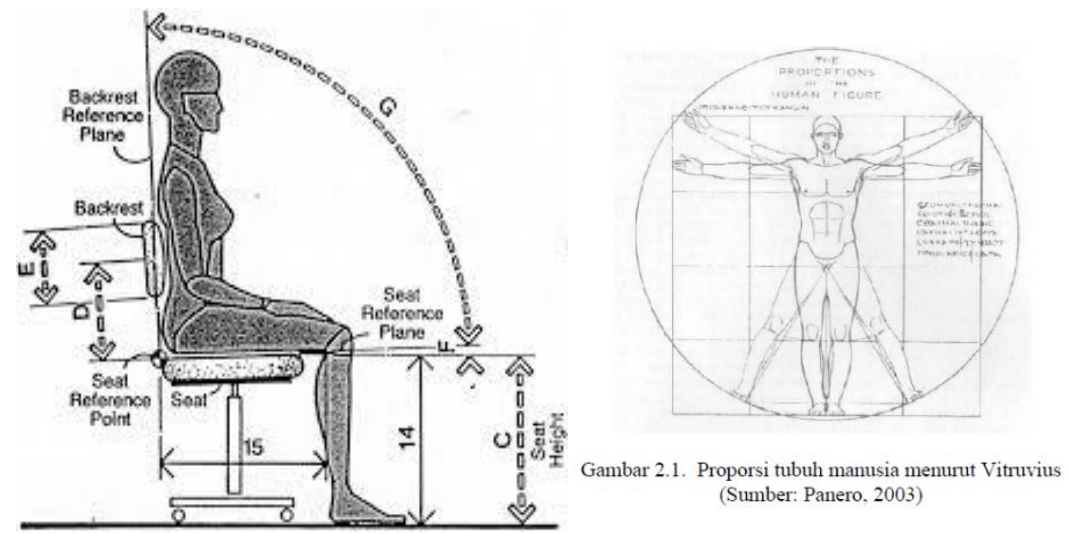

Gambar 3. Proporsi Tubuh Manusia. (Sumber: Panero,2003) 


\section{METODE PENELITIAN DAN ANALISA}

Penelitian ini menggunakan metode Deskriptif, dimana perolehan data yang selanjutnya digunakan sebagai bahan analisis dan diinterpretasikan kedalam penelitian. Metode ini digunakan untuk memperoleh data tentang ketertarikan stool terhadap pasar dan pengguna ruang publik hingga privat dari responden. Adapun responden yang ditargetkan terbagi menjadi 3 kategori

- Masyarakat umum/ civitas akademik non basic desain yang awam mengenai pengetahuan stool. Pertanyaan mencangku area umum atau ketertarikan danpengetahuan.

- Mahasiswa desain yang mengenal stool atau sekedar tau tentang stool. Pertanyaan melingkupi proses untuk meghasilkan sebuah stool yang ergonomis.

- Penikmat kuliner dengan media foodtruck

Metode Dokumentasi yang diaplikasikan pada penelitian adalah mengambil potret ataupun gambaran pasaran stool yang berkembang pada masyarakat seperti tren majalah, dan peraturan dengan ketentuan yang berlaku untuk stool, dan dokumentasi hasil survey pada pengaplikasian bentuk-bentuk stool untuk area foodtruck.

Data yang didapatkan kemudian diolah disajikan dalam susunan yang rapi dengan menghitung jumlah atau frekuensi mengenai pengaruh desain interior pada foodtruck terhadap minat berkunjung pengguna jasa foodtruck berdasarkan data hasil pembagian 31 kuesioner yang diolah untuk mendapatkan nilai dalam presentase realistis.

\section{HASIL PENELITIAN}

Pada studi kasus takoman, foodtruck penyedia menu jepang (takoyaki), penggunaan furniture masih pada fokus penghematan ruang packing tanpa memperhatikan sisi estetika dan keterkaitan konsep yang dibawa oleh foodtruck itu sendiri. Dari aplikasi warna, betuk dan kesinambungan dengan elemen interior tidak berkaitan sama sekali. Jenis furniture yang dipakai adalah stacking dan folding style, dengan alasan mempermudah pengemasan dan penyimpanan saat mobil berjalan, dan efektifitas waktu terhadap persiapan pembukaan foodtruck. Dari pertimbangan tersebut muncullah masalah sosial yang berkaitan dengan fungsional foodtruck atau tujuan pasaran foodtruck itu sendiri.

Pada jenis mebel yang dipilih oleh owner foodtruck adalah fabrikasi furniture, dengan mempertimbangkan kapasitas muatan yang disediakan dalam ruang lingkup foodtruck dan ketika foodtruk beroperasi. Dalam perancangan mebel, terutama foodtruck dapat diperhatikan sisi dimensi yang disediakan oleh user, dan kapasitas tampungan penyimpanan, selain memperhatikan bentuk yang menjadi daya tarik bagi pengguna, oleh karena itu perancangan stool harus menjadi sesuatu yang menjawab permasalahan dari sebuah aktivitas, kapasitas dan intergritas sebuah desain yang berkelanjutan dalam sebuah ruang. 


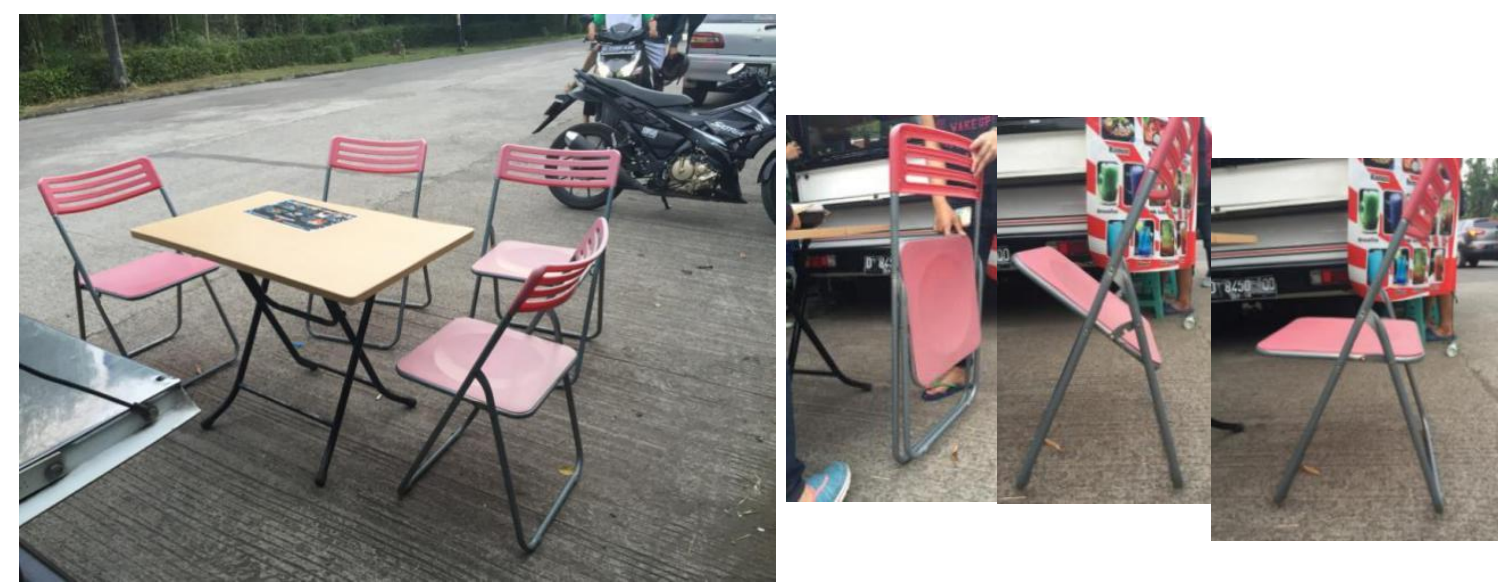

Gambar 4. Kursi Takoman

Pengguna foodtruck dominan dalam sebuah area adalah pesinggah atau sementara, bersifat tidak permanen dan cenderung stabil dalam sebuah statistika pengukuran ruang, dari ilustrasi dapat diperhatikan banyak karakteristik yang menjadi daya tarik dalam sebuah branding foodtruck. Tingkat kenyamanan dalam penataan ruang hingga keamanan yang terjamin dari sebuah pergerakan sosial dalam area foodtruck. Adapun strata sosial yang menjadi bagian terpenting dari sebuah kuliner.

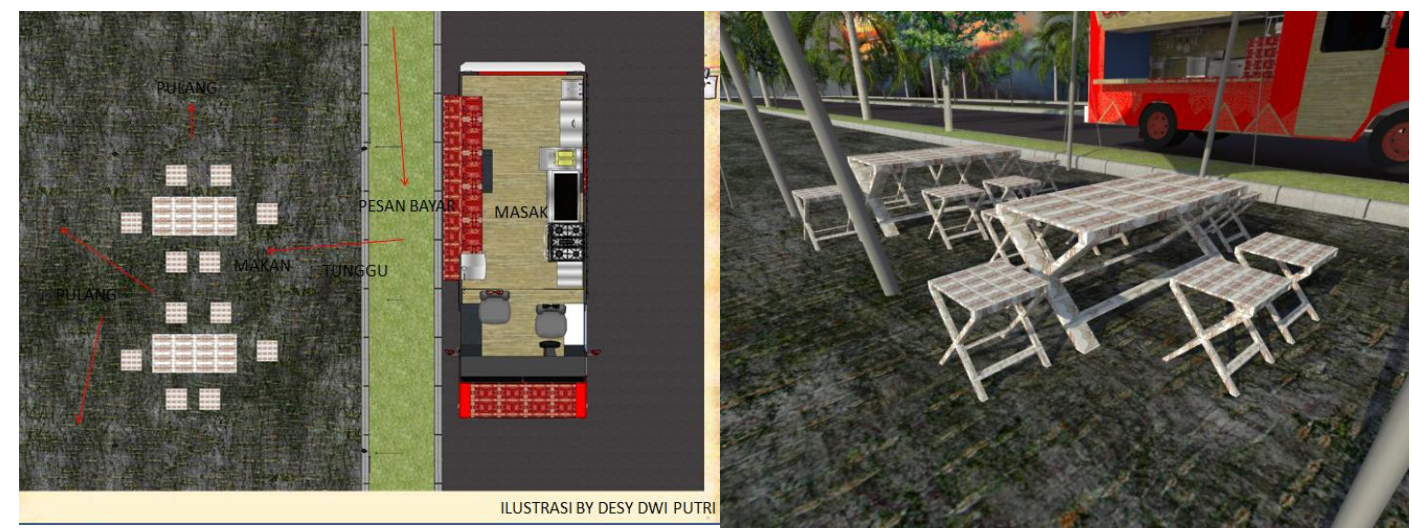

Gambar 5. ilustrasi stool

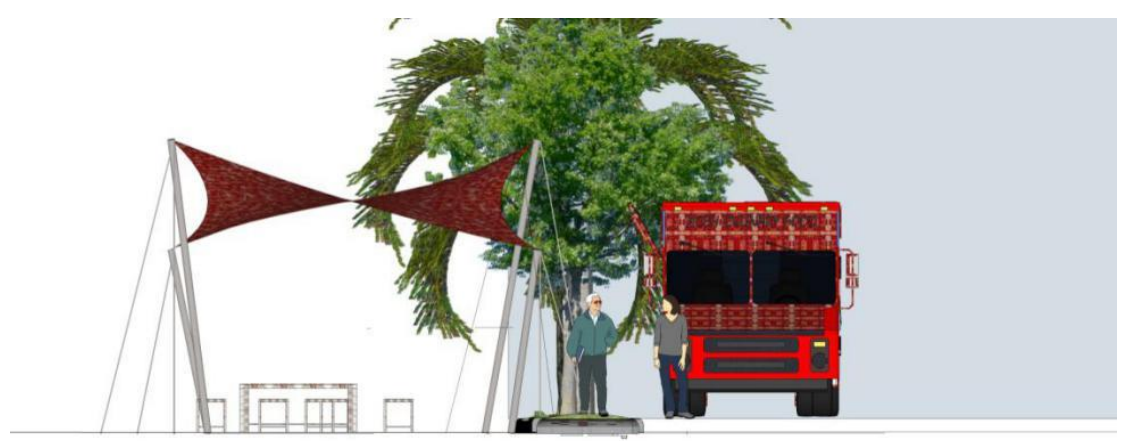

Gambar 6. Desain tata letak furniture 
Hasil kuesioner yang diperoleh di lapangan adalah sebagai berikut :

Tabel 1. Hasil Kuisioner

\begin{tabular}{|c|c|c|}
\hline \multirow{3}{*}{ Apakah anda pernah ke foodtruck? } & Pernah & 16 \\
\hline & tidak & 1 \\
\hline & Lewat & 10 \\
\hline \multicolumn{3}{|c|}{$\begin{array}{l}16 \text { dari } 27 \text { pernah ke foodtruck, } 1 \text { dari } 27 \text { tidak pernah, dan } 10 \text { dari } 27 \text { Cuma sekedar } \\
\text { lewat. Dari sample tersebut dapat disimpulkan bahwa masyarakat dominan mengetahui } \\
\text { tentang foodtruck dan pernah melihat foodtruck. }\end{array}$} \\
\hline \multirow{3}{*}{$\begin{array}{l}\text { Apakah anda merasa nyaman makan di } \\
\text { area foodtruck? }\end{array}$} & nyaman & 10 \\
\hline & tidak & 8 \\
\hline & biasa saja & 9 \\
\hline \multicolumn{3}{|c|}{10 dari 27 merasa nyaman, 8 dari 27 tidak, 9 dari 27 biasa saja. } \\
\hline \multirow{2}{*}{$\begin{array}{l}\text { Apakah tempat duduk di area foodtruck } \\
\text { dibutuhkan oleh anda? }\end{array}$} & Butuh & 26 \\
\hline & Tidak & 1 \\
\hline \multicolumn{3}{|c|}{$\begin{array}{l}26 \text { dari } 27 \text { merasa butuh dan } 1 \text { dari } 27 \text { tidak. Dapat disimpulkan bahwa dibutuhkan area } \\
\text { duduk disekitar foodtruck. }\end{array}$} \\
\hline \multirow{2}{*}{$\begin{array}{l}\text { Apakah susunan furniture disekitar } \\
\text { foodtruck mengganggu proses anda } \\
\text { membeli/memesan makanan? }\end{array}$} & $\mathrm{Ya}$ & 8 \\
\hline & Tidak & 19 \\
\hline \multicolumn{3}{|c|}{$\begin{array}{l}8 \text { dari } 27 \text { merasa terganggu, dan } 19 \text { dari } 27 \text { merasa tidak. Dapat disimpulkan bahwa } \\
\text { sirkulasi pada area foodtruck sudah memenuhi standar kenyamanan pengguna. }\end{array}$} \\
\hline \multirow{2}{*}{$\begin{array}{l}\text { Apakah bentuk tempat duduk } \\
\text { mempengaruhi daya tarik anda untuk } \\
\text { singgah di foodtruck? }\end{array}$} & $\mathrm{Ya}$ & 22 \\
\hline & tidak & 5 \\
\hline \multicolumn{3}{|c|}{$\begin{array}{l}22 \text { dari } 27 \text { menyatakan iya, } 5 \text { dari } 27 \text { tidak. Dapat disimpulkan bahwa tempat duduk di } \\
\text { area foodtruck sangat mempengaruhi daya tarik pengunjung selain makanan yang } \\
\text { disediakan. }\end{array}$} \\
\hline
\end{tabular}

Dari kesimpulan kuesioner diatas, masyarakat dominan mengetahui tentang foodtruck dan pernah melihat foodtruck, dibutuhkan area duduk disekitar foodtruck, sirkulasi pada area foodtruck sudah memenuhi standar kenyamanan pengguna, dan tempat duduk di area foodtruck sangat mempengaruhi daya tarik pengunjung selain makanan yang disediakan. 


\section{DISKUSI/PEMBAHASAN}

Pada diskusi pembahasan akan dibahas tentang hasil desain stool di Fakultas Industri Interior pada objek mock up stool 1:5 .

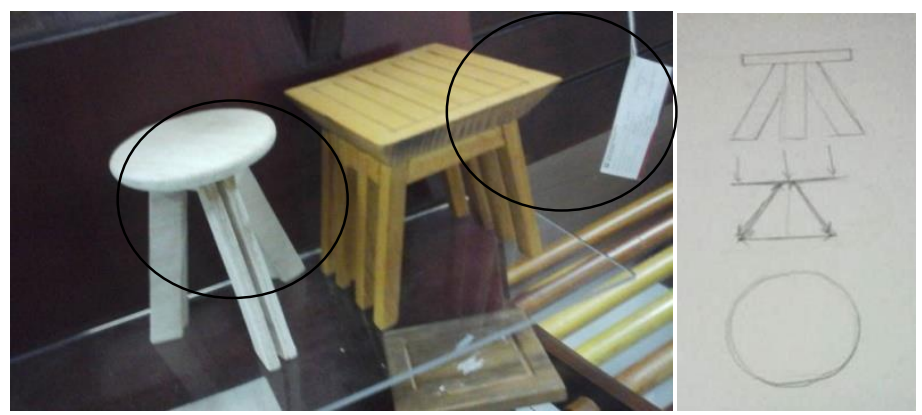

Gambar 7. objek 1

Objek 1 : penggunaan elemen lingkaran dan persegi mewakili sifat dari masing-masing kategori. Lingkaran identik dengan dinamis dan santai, sedangkan persegi identik dengan ketegasan. Dalam pemilihan jenis stool pada foodtruck dapat dipilih berdasarkan konsep dari pembawaan foodtruck.

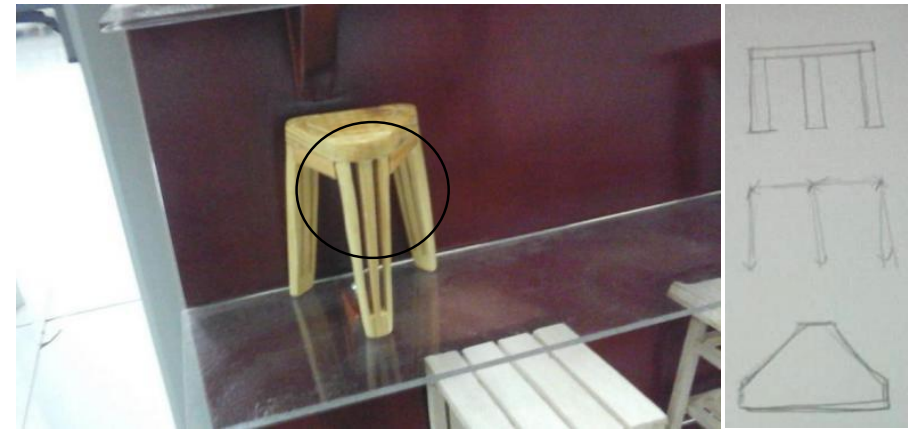

Gambar 8. objek 2

Objek 2 : dua bentuk dari geometri yaitu perpaduan lingkaran dengan segitiga.

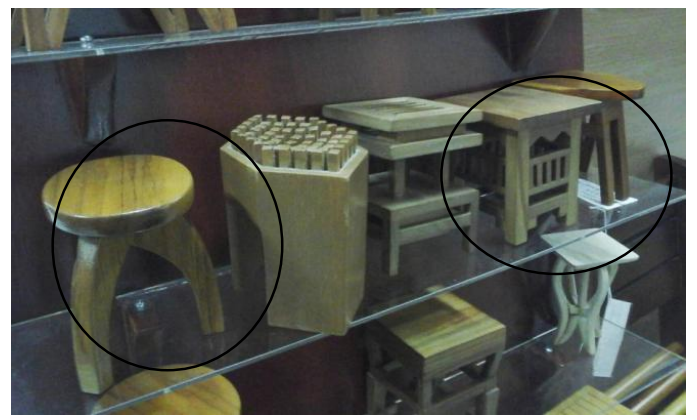

Gambar 9. objek 3

Objek 3 lingkaran, perpaduan dimensi, dan perpaduan geometri dalam sebuah pengonsepan 


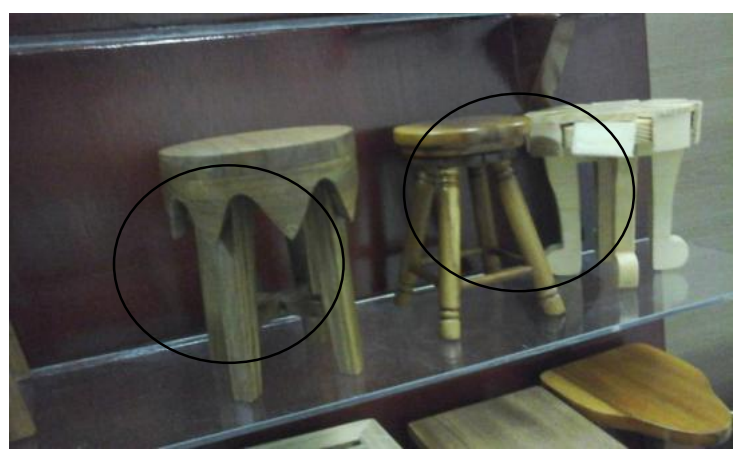

Gambar 10. objek 4

Objek 4 stilasi bentuk dengan keterkaitan tema dan aplikasi langgam ornament pada stool
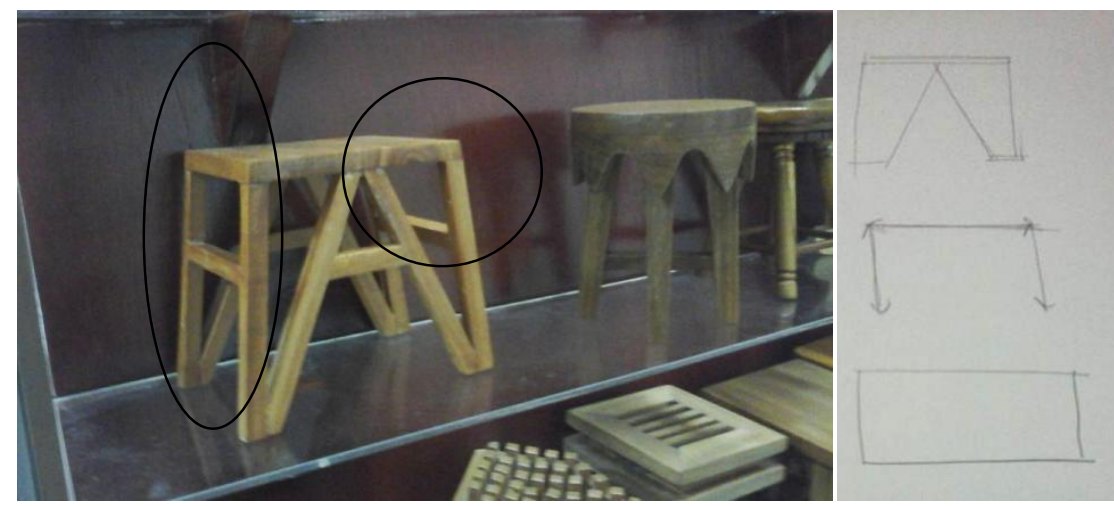

Gambar 11. objek 5

Objek 5 penggabungan dua bentuk yang dipadukan sebagai konstruksi yaitu segitiga dan persegi.
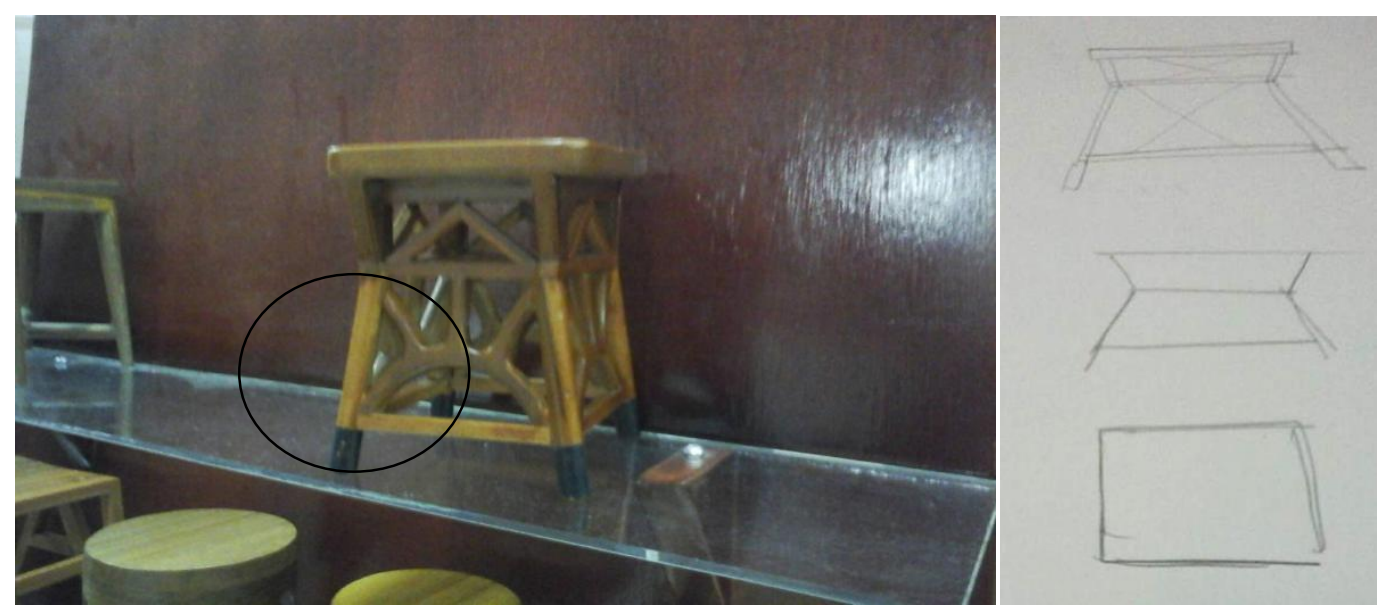

Gambar 12. objek 6

Objek 6 penggabungan dua bentuk yang dipadukan dan distilasikan berdasarkan konsep segitiga dan lingkaran 
Dalam mendesain sebuah stool, realisasi bentuk tidak dibatasi dengan beberapa perpaduan apapun, akan tetapi prinsip ketepatan sesuai fungsi dan juga berkaitan denga kapasitas dari penampungan pada ruang, dan aktivitas yang dilakukan dari sebuah objek yang mendukung objek lainnya dalam interaksi sosial. Hal terpenting dari sebuah mebel adalah system konstruksi dalam menahan beban yang tidak bisa diperkirakan dalam sebuah area publik.

\section{KESIMPULAN}

Dalam sebuah perancangan harus dikaji dari segala aspek penggunaan ruang hingga aktivitas yang berlangsung, dari dominan maupun aksen. Perancangan yang baik adalah yang menjawab permasalahan aktivitas, kapasitas dan sinergisitas dari sebuah komponen perekonomian yang berkembang dalam siklus masyarakat. Ketertarikan visual pada sebuah aspek didukung dari perancangan yang seharusnya menjadi bagian dari perancangan stool sebagai pelengkap komponen geometri yang mewakili setiap sifat ruang, konsep, tema dan fungsi secara keseluruhan.

Bentuk geometri sangat berpengaruh dalam aksebilitas pengguna area foodtruck, penepatan dalam luasan area terbatas menjadi acuan desain yang harus mempertimbangkan bentuk untuk keselamatan dalam pergerakan user. Pengaplikasian bentuk pada stool foodtruck yang mendukung adalah bentuk sederhana yaitu persegi, lingkaran, octagonal dan persegi panjang. Dalam bentuk yang aman untuk aktifitas area sempit terbatas maupun kapasitas area luas yang aman dan nyaman dalam akses menuju area utama yaitu pelayanan. Stool yang berbentuk geometri sederhana dan pendukung utama dalam pengaplikasian stacking system dan bongkar pasang sebagai komponen foodtruck saat digunakan maupun saat packing system.

\section{DAFTAR PUSTAKA}

Panero, Julius dan Martin Zelnk ,1979, Human Dimension \& Interior Space, New York: Watson-Guptill Publications

Arikunto, Suharmisi, 2002, Metode Penelitian , Jakarta: PT. Rineka Cipta

Mardalis, 2008, Metode PenelitianSuatu Pendekatan Proposal, Jakarta: Bumi Aksara

Mercer, 1969, Sejarah Perkembangan Desain Furniture :Analisa Penerapan Gaya Desain dan Eksplorasi Bentuk yang Digunakan Mahasiswa pada Mata Kuliah Desain Mebel I Fakultas Desain Unikom, Jurnal Ilmiah Unikom. Vol. 12 No.2

Tikno, I, 2008, Mengenal Konstruksi Kayu untuk Furniture dan Bangunan, Jakarta: Esensi Surtisno, R, 1984, Bentuk Struktur Bangunan Dan Arsitekture Modern, Jakarta : Gramedia Sukmadinata, 2006, Metode Penelitian Pendidikan, Bandung : Remaja Rosada Karya

Sutrisno, 1984, Pengertian Stool : Analisa Penerapan Gaya Desain dan Eksplorasi Bentuk yang Digunakan Mahasiswa pada Mata Kuliah Desain Mebel I Fakultas Desain Unikom, Jurnal Ilmiah Unikom. Vol. 12 No. 2 Accesed 06/10/2018.

Sutalaksana, 1979, Teknik Tatacara Kerja : Perancangan Meja dan Kursi Kerja yang Ergonomis pada Stasiun Kerja Pemotongan sebagai Upaya Peningkatan Produktivitas, Jurnal Ilmiah Teknik Industri. Vol.10 No.2 Tahun 2011. Accesed 06/10/2018.

Pheasant, 1987, Perancangan Meja Kursi Ergonomis pada Pembatik Tulis di Kelurahan Kalinyamat Wetan Kota Tegal. Jurnal Ilmiah Teknik Industri. Vol 12 No.02 Tahun 2013. Accesed 06/10/2018 